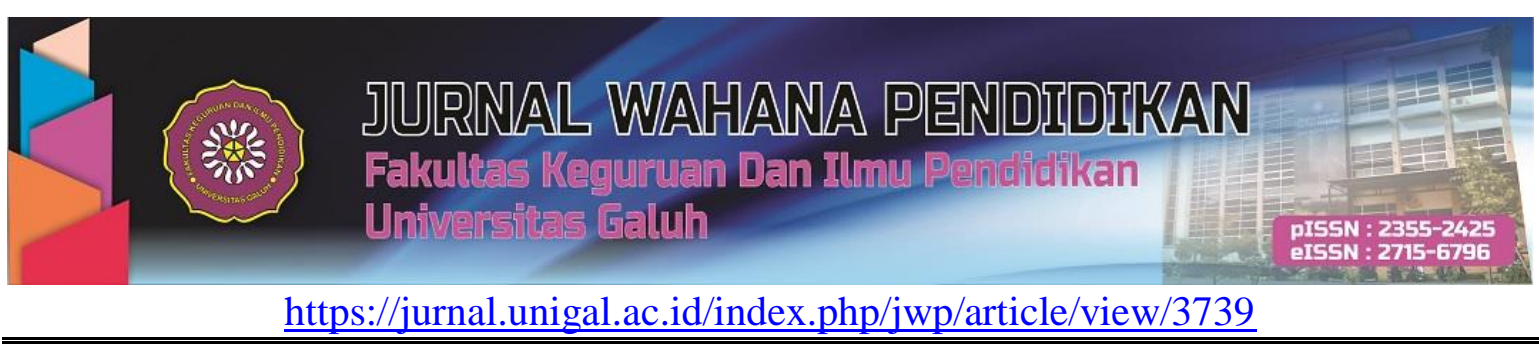

\title{
KETERAMPILAN PROSES CALON GURU PADA PEMBELAJARAN SAINS ANAK USIA DINI
}

\author{
Ervin Siwi Arti ${ }^{1}$ \\ 1IKIP PGRI Jember, Jember, Jawa Timur, Indonesia \\ Email: ervinsiwia03@gmail.com
}

\begin{abstract}
Human Resources must be fostered since school or college. One of the efforts in fulfilling qualified Human Resources is the education of prospective teachers. Educators or often called teachers have the responsibility to provide support and motivation so that every student gets the best education services. To obtain this, process skills need to be trained in early childhood science learning. the purpose of the study was to determine the initial ability of the process skills of prospective PAUD teachers. Research using the observation method. The process skills that need to be improved are the communication aspects so that efforts are needed to empower science learning. while the aspects of observation, classification and inferring the good category
\end{abstract}

Keywords: Process Skill, Science learning, Early Childhood

\section{ABSTRAK}

Sumber Daya Manusia harus dibina sejak bangku sekolah atau kuliah. Salah satu upaya dalam pemenuhan Sumber Daya Manusia yang berkualitas adalah pembinaan pendidikan calon guru. Pendidik atau sering disebut guru mempunyai tanggung jawab untuk memberi dukungan serta motivasi agar setiap anak didik mendapatkan layanan pendidikan terbaik. Untuk memperoleh hal tersebut perlu dilatihkan keterampilan proses pada pembelajaran sains anak usia dini. Tujuan penelitian untuk mengetahui kemampuan awal keterampilan proses calon guru PAUD. Penelitian menggunakan metode observasi. Keterampilan proses yang perlu ditingkatkan adalah aspek komunikasi sehingga diperlukan upaya memberdayakan pembelajaran sains. Sedangkan aspek observasi, klasifikasi dan menyimpulkan pada kategori baik

Kata Kunci:Keterampilan Proses, Pembelajaran Sains, Anak Usia Dini

Cara sitasi: Arti, ES. (2020). Keterampilan Proses Calon Guru Pada Pembelajaran Sains Anak Usia Dini. Jurnal Wahana Pendidikan, 7 (2), 135-140 


\section{PENDAHULUAN}

Keberhasilan pendididikan dalam setiap jenjang sangat ditunjang oleh adanya pendidik yang memiliki komitmen dan dedikasi yang tinggi. Standar Kompetensi Pendidik Pendidikan Anak Usia Dini (PAUD) terdiri dari sifat karakter, kualitas emosional, kesehatan fisik, dan kesehatan mental. Lebih lanjut Gordon \& Browne (2011), bahwa pendidik PAUD juga harus memiliki keterampilan.Keterampilan salah satunya adalah adalah keterampilan proses. Hal serupa yang dijelaskan diatas juga harus dimiliki oleh calon guru PAUD.

Keterampilan proses meliputi keterampilan mengamati, mengajukan hipotesis, menggunakan alat dan bahan secara baik dan benar dan selalu mempertimbangkan keamanan dan keselamatan kerja, mengajukan pertanyaan, menggolongkan dan menafsirkan data serta mengkomunikasikan hasil temuan secara lisan atau tertulis. Keterampilan proses penting dilaksanakan karena proses belajar sama pentingnya dengan hasil belajar. Keterampilan proses adalah aktivitas fisik dan mental serta kompetensi yang harus dikuasai dan aplikasikan siswa agar pembelajaran sains lebih efektif (Akinbobola \& Afolabi, 2010). Penguasaan Keterampilan Proses Sains yang baik akan menghasilkan hasil belajar maksimal (Prasasti, 2017)

Pembelajaran sains anak usia dini bertujuan agar memiliki kemampuan memecahkan masalah yang dihadapinya. Cara-cara proses pengenalan objek sains yang benar perlu diperkenalkan sejak awal oleh guru atau calon guru. Tantangan mengajar abad 21 diantaranya adalah mengajar untuk kostruksi makna. Perspektif konstruktivis tidak melihat pengetahuan sebagai sesuatu yang sepenuhnya diketahui tetap dan dapat ditularkan tetapi berpendapat bahwa pengetahuan bersifat personal dan maknanya dikonstruksikan oleh siswa melalui pengalaman Arends (2008).

Kemendikbud (2018) menjelaskan pembelajaran anak usia dini menggunakan pendekatan saintifik. Tujuan pendekatan pembelajaran ini yaitu membangun cara berpikir agar anak memiliki kemampuan berpikir yang diperoleh melalui proses mengamati, menanya, mengumpulkan informasi, menalar dan mengomunikasikan hasil pemikirannya. Pendekatan saintifi $k$ akan memperkaya pengalaman belajar anak. Hal ini sejalan dengan penerapan keterampilan proses. Oleh sebab itu calon pendidik atau guru perlu memahami keterampilan proses yang berguna untuk bisa diterapkan pada anak didik.

\section{METODE PENELITIAN}

Penelitian ini merupakan penelitian kualitatif. Penelitian dilakukan di IKIP PGRI Jember pada Semester Gasal 2018/2019. Subjek penelitian terdiri dari 43 orang. Data dan sumber data keterampilan proses yaitu (a) Instrumen:Lembar Observasi Keterampilan Proses; (b) Teknik Pengambilan Data: Observasi (c) Sumber Data: Calon Guru (Mahasiswa) dan Dosen. Skor keterampilan proses siswa dikumpulkan melalui penjumlahan skor tiap indikator aspek keterampilan proses yang diperoleh oleh seluruh mahasiswa. Observasi keterampilan proses ini ini dilakukan oleh Dosen dan obsever.

Analisis data berupa data kuantitatif dan kualitatif. Data kuantitatif keterampilan proses hasil observasi dihitung untuk menentukan presentase keberhasilan, cara penghitungannya melalui rumus:

Presentase keberhasilan $=\sum \frac{\text { Skor yang dicapai }}{\text { jumlah maksimum }} \times 100 \%$

Data kuantitatif dianalisis untuk mengetahui tingkat keberhasilan. Dalam penilaian keterampilan proses didapatkan dari obsevasi guru dengan observer pada saat pembelajaran di kelas sesuai dengan indikator. Untuk menentukan kriteria keterampilan proses dibagi menjadi beberapa tindakan dan taraf keberhasilan yaitu (a) 80-100\% : Sangat Baik; (b) 60-79: Baik; (c) 5559: Cukup; (d) 50-54: Kurang; (e) $\leq 49$ : Sangat Kurang 
Tabel 1.

Tingkat Keberhasilan Keterampilan Proses dan Sikap IImiah

\begin{tabular}{cc}
\hline Kategori Tindakan (\%) & Taraf Keberhasilan \\
\hline $80-100$ & Sangat Baik \\
$60-79$ & Baik \\
$55-59$ & Cukup \\
$50-54$ & Kurang \\
$\leq 49$ & Sangat Kurang \\
\hline
\end{tabular}

HASIL DAN PEMBAHASAN

Keterampilan proses dari hasil observasi berdasarkan indikator yang terdapat pada rubrik belum sepenuhnya terlaksana. Untuk perolehan skor dapat dilihat pada Tabel 2.

Tabel 2.

Keterampilan Proses

\begin{tabular}{cccc}
\hline Aspek & $\begin{array}{c}\text { Jumlah Skor Keterampilan } \\
\text { Proses }\end{array}$ & $\begin{array}{c}\text { Jumlah } \\
\text { maksimal }\end{array}$ & $\begin{array}{c}\text { Presentase } \\
(\%)\end{array}$ \\
\hline Observasi & 363 & 516 & 70,34 \\
Klasifikasi & 377 & 516 & 73,06 \\
Berkomunikasi & 260 & 516 & 50,38 \\
Menyimpulkan & 194 & 258 & 75,19 \\
\hline
\end{tabular}

Keterampilan proses pada aspek observasi $(70,34 \%)$, klasifikasi $(73,06)$, dan menyimpulkan $(75,19 \%)$ berada pada kategori baik. Adapun kegiatan dari masing masing aspek yaitu (a) Observasi mahasiswa melakukan pengamatan objek secara seksama; (b) Klasifikasi mahasiswa menghubungkan data dan hipotesis dan mengolompokkan data objek berdasarkan kriteria tertentu; (c) Berkomunikasi mempresentasikan atau mengemukakan jawaban; (d) Menyimpulkan: mahasiswa membuat kesimpulan yang benar. Keterampilan proses membuat siswa mengembangkan pemahaman pemahaman konsep dengan mengkombinasikan pengetahuan dan keterampilan berpikir untuk mempelajari suatu objek (Simsek \& Kapabinar, 2010; Sheeba, 2013). Keterampilan proses dapat meningkatkan hasil belajar, dan membuat siswa memperoleh berbagai macam cara selama melakukan penelitian (Ergul et al, 2011).

Berdasarkan data tersebut terlihat bahwa keterampilan proses pada aspek komunikasi tergolong kurang. Hal ini disebabkan karena karakter mahasiswa yang tidak terbiasa menulis sebagai aspek komunikasi. Dalam pembelajaran mahasiswa menganggap hasil adalah sesuatu hal yang penting dari aspek lainnya tanpa melihat proses. Menurut Simon (Simon \& Zimmerman, 1990) keterampilan proses dapat menfasilitasi kegiatan, membuat siswa berpartisipasi, mengembangkan kemampuan berpikir, kemampuan berkomunikasi. Keterampilan proses dapat melatih aktivitas fisik dan mental serta kompetensi yang harus dikuasai dan aplikasikan agar pembelajaran lebih efektif (Akinbola \& Afolabi, 2010). Keterampilan proses yang dikembangkan dapat mengajak kemampuan berpikir dan bertindak yang efektif dan kreatif sesuai dengan yang dipelajari, karena keterampilan proses yang dikembangkan problem dan proses mendekati sesuai dengan dunia pembelajaran calon guru (mahasiswa).

Tujuan pembelajaran sains anak usia dini pada calon guru (mahasiswa) sejalan dengan tujuan kurikulum PAUD yaitu mengembangkan anak secara utuh baik pikiran hati maupun jasmani. Menurut Abruscato (1997) pendidikan sains anak usia dini dapat mengembangkan inelektual, emosi, fisik jasmani, atau aspek kognitif afektif dan psikomotor. Rumusan tujuan didasarkan pada pertimbangan bahwa tugas utama sekoalah adalah membantu anak mencapai kebutuhan sekarang maupun yang akan datang. Rumusan tujuan sains yang luas harus memperhatikan karakteristik pada anak usia dini. Pendidikan sains dapat mengembangkan individu serta mampu menggunakan aspek fundamental dalam memecahkan masalah. Hal ini berkaitan dengan keterampilan proses yang dilakukan calon guru (mahasiswa) guna mengajarkan kepada siswa atau peserta didik. 
Keterampilan proses menggali dan memilah informasi faktual yang relevan untuk untuk menguji gagasan-gagasan atau memecahkan masalah sehari-hari (Rezba, 2007).

\section{KESIMPULAN}

Keterampilan proses mengarahkan pada pengembangan kemampuan dasar berupa mental fisik, dan sosial untuk menemukan fakta dan konsep maupun pengembangan sikap dan nilai melalui proses belajar mengajar yang telah mengaktifkan mahasiswa sehingga mampu menumbuhkan sejumlah keterampilan tertentu pada diri mahasiswa.

Keterampilan proses memerlukan motivasi guru atau dosen yang mendorong siswa untuk mencari informasi yang dibutuhkan berupa pertanyaan. Kegiatan belajar dengan menggunakan keterampilan proses dipengaruhi oleh pendekatan yang digunakan oleh guru atau dosen

\section{REKOMENDASI}

Dengan adanya kegiatan keterampilan proses pembelajaran sains anak usia dini diharapkan pada calon guru (mahasiswa) dapat memberikan pembelajaran yang sesuai dengan karakteristik anak usia dini

\section{UCAPAN TERIMAKASIH}

Penulis mengucapkan terimakasih kepada semua yang telah terlibat penelitian sampai terbitnya penulisan ini.

\section{DAFTAR PUSTAKA}

Abruscato, Josep. (1997). Teaching Children Science. USA: Prentice-Hall.Inc

Akinbobola, A.O\& Afolabi, F. (2010). Analysis of Science Process Skill in West African Senior Secondary Shool Certificate Physics Practical Examinations in Nigeria. American Eurasian Journal of Scientific Research 5 (4): 234-240.

Arends, R. J. (2008). Learning to Teach. Yogyakarta: Pustaka Pelajar.

Ergul, R., Simsekli, Y. (2011). The Effect Inquiry Based Science Teaching on Elementary School Students Science Prosess Skill and Science Attitude, Bulgarian Journal Of Science and Education Policy Education, 5 (1): 46-68

Gordon, A.M\&Browne, K.W. (2011). Beginning and Beyond: Foundations in Early Childhood Education.Australia: Wadswort Cengage Learning

Kemendikbud. (2018). Pedoman Pengelolaan Pembelajaran Pendidikan Anak Usia Dini. Kemendikbud: Direktorat Jenderal Pendidikan Anak Usia Dini dan Pendidikan Masyarakat.

Prasasti, Pinkan Amita Tri. (2017). Efektivitas Scientific Approach With Guided Experiment pada Pembelajaran IPA untuk Memberdayakan Keterampilan Proses Sains Siswa Sekolah Dasar. Jurnal Profesi Pendidikan Dasar. Vol. 4, No. 1.

Rezba, R.J. (2007). Learning and Assesing Science Process Skill. lowa: Kendall Publishing Company

Sheeba, M.N. (2013). An Anatomy Of Science Process Skill In The Light Of The Chalenges To Realize Science Instruction Leading To Global Excellence In Education. Education Confab, 2 (4): 108-123

Simon, M.S., Zimmerman, J.M. (1990). Science and Writing . Science and Children, 18(3): 7-8

Simsek \& Kapabinar. (2010). The Effects of Inquiry-Based Learning on Elementary Students Conceptual Understanding of Matter, Scientific Process Skill and Science Attitude. Procedia Social and Behavioral Science(2): 1190-1194. 